\title{
The impact of melatonin administration on the fertility performance and several relating parameters during the breeding season in the Arabi ewes
}

\author{
W.Y. Kassim ${ }^{1}$, K.A. Al-Rishdy ${ }^{1}$ and M.F. AL-Helou ${ }^{2}$ \\ ${ }^{1}$ Department of Animal Production, College of Agriculture, ${ }^{2}$ Department of Biology, College of Education/Qurna, \\ University of Basrah, Basrah, Iraq
}

(Received December 17, 2018; Accepted May 15, 2019)

\begin{abstract}
A total of twenty-four healthy ewes aged between 2-3 years old and weighed about $35.09 \mathrm{~kg}$ of body weight were divided randomly into four groups ( 6 animals for each group). The first group included the non-treated control group, while the other three groups were subjected to various oral doses of melatonin $9 \mathrm{mg}, 12 \mathrm{mg}$ and $15 \mathrm{mg} / \mathrm{head}$, respectively. All treatments were applied at 6 o'clock in the morning, to investigate the effect of treatment with melatonin during breeding season on reproductive performance and levels of some biochemical parameters in Arabi ewes from 1 May to 1 October 2017. Blood samples $7 \mathrm{ml}$ were collected after one hour of treatment and then monthly during the pregnancy months to determine the concentrations of biochemical parameters. After Postpartum, lambed ewes/lambs number, birth weight, placenta empty weight and cotyledon number were recorded. The results showed significant $(\mathrm{P}<0.05)$ improvement in reproductive performance (fertility percentage, twinning rate and the number of offspring) when ewes administrated melatonin at two doses (12 and 15 $\mathrm{mg} /$ head). Also, melatonin administration caused significant $(\mathrm{P}<0.05)$ decrease in the concentrations of thyroxin, cortisol, and cholesterol. Conversely, there was a significant increase $(\mathrm{P}<0.05)$ in glucose concentration after 1 hour of treatment. The concentrations of thyroxin, cortisol, cholesterol, and vitamin $\mathrm{C}$ increased significantly $(\mathrm{P}<0.01)$ in early-gestation compared with mid and late-gestation, while the concentrations progesterone and glucose increased significantly $(\mathrm{P}<0.05)$ in midgestation compared with early and late-gestation. In conclusion, melatonin administration at doses 12 and $15 \mathrm{mg} / \mathrm{head}$ improves ewe reproductive performance (fertility percentage, twinning rate and the number of born lambs). Additionally, the gestation stage has a negative effect on the concentrations of thyroxin, cholesterol and vitamin $\mathrm{C}$.
\end{abstract}

Keywords: Melatonin, Ewes, Biochemical parameters, Reproductive Available online at http://www.vetmedmosul.com

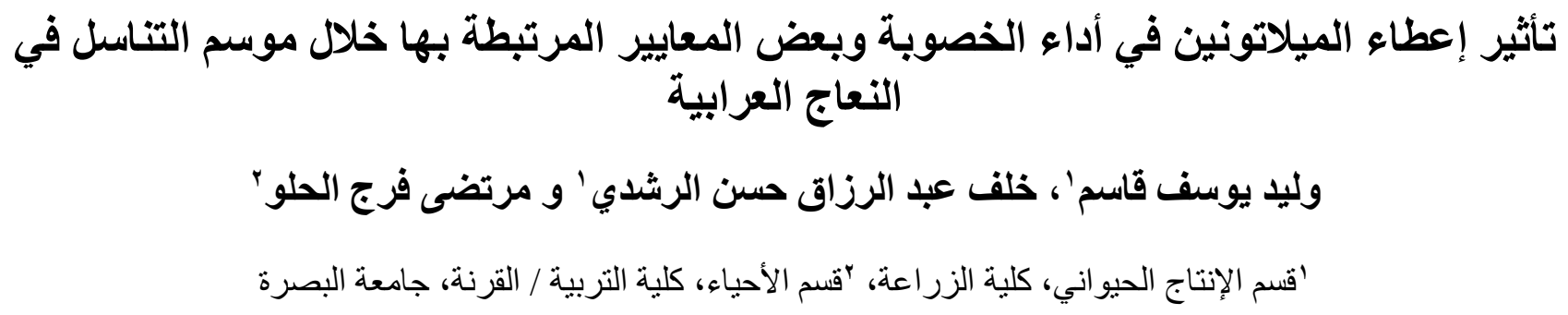

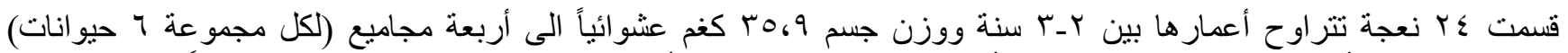

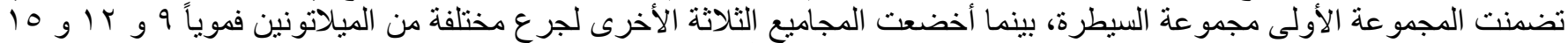

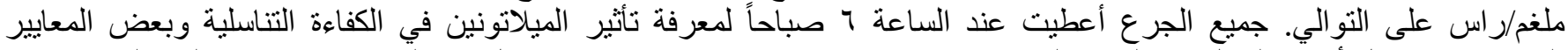

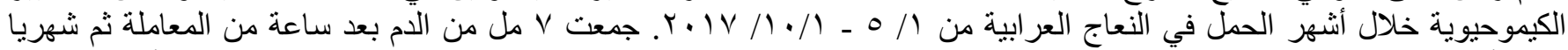

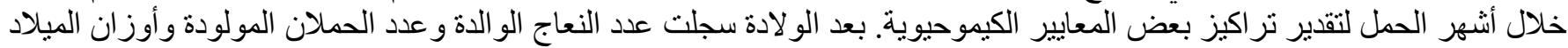

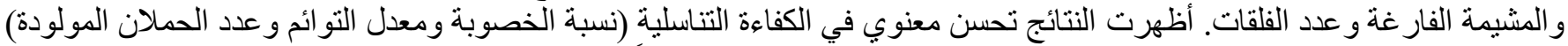
عندما عوملت النعاج با و و المة ملغن/ راس من الميلاتونين، وانخفضت معنوياً تراكيز الثيروكسين والكورنيزول و الكولسترول، بينما 


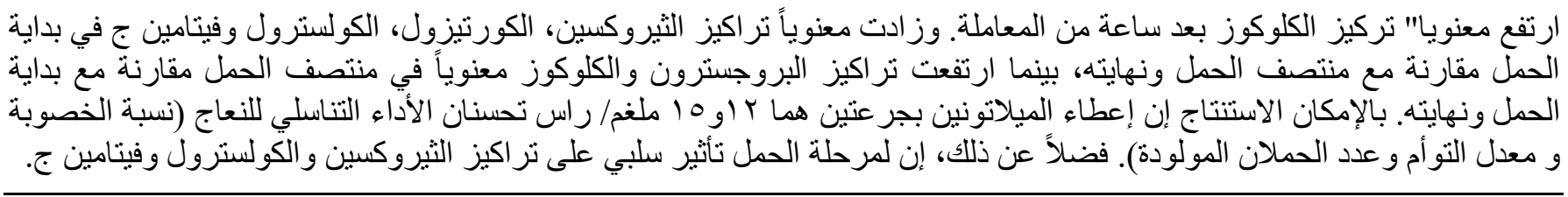

\section{Introduction}

Arabi is the major breed of sheep in the south of Iraq characterized by their ability to mating during all the year with a low fertility percentage. Usually, the breeding season begins in May and continues to the end of June, thus most of ewes lambing occurs in October until November and this allows the ewes to lambing before winter (1).

The reproduction in ewes could be influenced by many pathways such as changes in sexual behavior, fertility, estrus cycle, a rise in sexual hormone secretion and successful of mating between ewes and rams. The successful of mating, pregnancy and expressing of fertility are very important to farmers and supply them more commercial yield. Therefore, many researchers attempted to use different methods such as genetic improvement, flushing and estrus synchronization to improve reproductive efficiency. One of those ways is treating ewes with melatonin (2).

Melatonin is classified as one of the neuro - hormones produced and release rhythmically from the pineal gland (3). Melatonin rises and declines in response to lighting conditions (4). The receptors of this hormone are diffusion in different body areas such as brain and some peripheral tissues (5). Hypothalamus, ovary, and testes are affected by the changes in melatonin levels in serum, which provide a critical neuron signal to regulate the release of sexual hormones primarily from the hypothalamus (gonadotropin releasing hormone $\mathrm{GnRH}$ ) and then from gonadal glands to induce the reproduction season $(6,7)$. The main function of melatonin is stimulated and regularization the estrus cycle outside breeding season in animals, which depends on photoperiod by stimulating the secretion of GnRH from the hypothalamus-pituitary-gonadal axis, leading to organizing secretion of luteinizing hormone (LH) and follicle stimulating hormone (FSH) $(8,9)$. Reported (10) that there is a relationship between melatonin secretion and decrease in light-day hours. The response of ewes for melatonin treatment depends on some factors such as nutrition, breed, age, body condition and season $(2,11)$.

Although, Arabi ewes could be bred during all year, and the pineal gland can secrete melatonin naturally to stimulate the estrus cycle. The extra amount of melatonin, which is provided by the administration will help and lead to improvement the fertility (12). Therefore, the aim of this study was to find the effect of melatonin administration on fertility, and some biochemical parameters in Arabi ewes.

\section{Materials and methods}

The study was conducted on one of the commercial animal farms in Al-Qurna (76 km north of Basrah state, Iraq) during the period between 1 May to 1 October 2017. The aims of the present study were to investigate the effect of treatment with melatonin during breeding season on reproductive performance and some biochemical parameters before and during pregnancy in Arabi ewes. A total of twenty-four healthy ewes aged between 2-3 years and weighed $35.09 \mathrm{~kg}$ were divided randomly into four groups (6 animals for each group) The first group included the non-treated control group, while the other three groups were subjected to various oral doses of melatonin $(9 \mathrm{mg}$, $12 \mathrm{mg}$ and $15 \mathrm{mg} / \mathrm{head}$, respectively. Melatonin manufactured by Ltd Nature Made- U.S.A.). All treatments were applied at 6 o'clock in the morning. All animals were marked and vaccinated with CO-Baghdad inoculator before one month of the experiment. After treatment, four rams were selected carefully (characterized by high fertility) and mated with ewes. During the study, animals were grazed about 5 hours in the morning and 3 hours in the evening. Between those two periods, animals were fed the same concentrate diet $(250 \mathrm{~g} / \mathrm{head})$ with offer ad libitum good quality water and trace mineral block.

After fasting for eight hours, seven $\mathrm{ml}$ of blood was collected from the jugular vein after one hour of treatment and then monthly during the gestation period. Blood samples were taken into heparinized tubes and plasma were separated by centrifugation at $3000 \mathrm{rpm}$ for 15 minutes and were frozen at $-20 \mathrm{C}^{\circ}$ until analysis. After postpartum, lambed ewes/lambs number, birth weight, placenta empty weight and cotyledon number were recorded.

The concentration of albumin was determined by using a chemical kit the France Biolabo SA, Company. The glucose concentration was measured by chemical kit of the England Plamatec Company. The total protein and cholesterol concentrations were determined by using a chemical kit of the France Biomeriex Company. Vitamin C concentration was measured by using the method of (13). Progesterone, thyroxin, TSH (Thyroid stimulating hormone) and cortisol concentrations were determined by using a procedure described with the kit of Monobind Inc.USA company.

The obtained data were analyzed statistically using the (14) software package with one-way analysis of variance. 
Statistically significant differences were determined at $\mathrm{P}<0.05$.

\section{Results}

The effect of different levels of melatonin on reproductive performance of Arabi ewes was presented in Table 1. Ewes treated with melatonin at two dosages 12 and $15 \mathrm{mg} /$ head showed an increase in the lambed ewes number, percentage of fertility and twinning and lambs number as compared with control and T2 groups. The number of barren ewes was higher in control and $\mathrm{T} 2$ groups as compared with other treated groups. There was a significant increase in placenta weight when ewes treated with melatonin at a dose of $12 \mathrm{mg} /$ head in comparison with other groups. There were no significant differences observed between groups in total litter weight and cotyledon number.

Table 1: Effect of different doses of melatonin on reproductive performance of ewes (Mean $\pm \mathrm{SE}$ )

\begin{tabular}{lcccc}
\hline Trails & \multicolumn{3}{c}{ Groups } & T3 \\
\cline { 2 - 5 } & Control & T1 & T2 & 6 \\
\hline Total no. & 6 & 6 & 6 & 6 \\
Lambed ewes (No.) & 3 & 5 & 6 & 0.00 \\
Barren ewes (No.) & 3 & 1 & 100 & 100 \\
Fertility (\%) & 50 & 83 & 50.0 & 33.3 \\
Twin (\%) & 0.00 & 0.00 & 9 & 8 \\
Lambs (No.) & 3 & 5 & $0.10 \pm 3.34$ & $0.09 \pm 3.22$ \\
Total litter weight (kg) & $3.08 \pm 0.11$ & $0.09 \pm 3.12$ & $9.12 \mathrm{c} \pm 282$ & $9.54 \mathrm{c} \pm 254$ \\
Placental weight (g) & $10.9 \mathrm{~b} \pm 306$ & $11.3 \mathrm{a} \pm 350$ & $1.88 \pm 38.22$ & $1.76 \pm 37.75$ \\
Cotyledon (No.) & $1.98 \pm 34.33$ & $1.76 \pm 35.80$ &
\end{tabular}

Different small letter within class means significant difference $(\mathrm{P}<0.05)$ between groups.

The effect of different doses of melatonin on numerous hormone concentration in plasma was presented in Table 2. The concentration of thyroxin hormone was decreased significantly in all treated groups as compared with control. Mean values of the concentration of cortisol after melatonin treatment indicated a significant decrease.

The effect of different doses of melatonin on some biochemical parameter concentrations in plasma was presented in Table 3. No significant differences were obtained between groups in total protein and albumin concentrations after 1 hour of melatonin treatment.
Table 2: Effect of different doses of melatonin on numerous hormone concentrations $(\mathrm{ng} / \mathrm{ml})$ in plasma after 1 hour of treatment $($ Mean $\pm \mathrm{SE})$

\begin{tabular}{lccc}
\hline \multirow{2}{*}{ Groups } & \multicolumn{3}{c}{ Hormones } \\
\cline { 2 - 4 } & Progesterone & Thyroxin & Cortisol \\
\hline Control & $1.89 \pm 0.09$ & $51.89 \pm 4.08 \mathrm{a}$ & $85.01 \pm 5.61 \mathrm{a}$ \\
T1 & $1.32 \pm 0.10$ & $46.10 \pm 3.05 \mathrm{~b}$ & $67.21 \pm 4.31 \mathrm{~b}$ \\
T2 & $1.45 \pm 0.08$ & $45.61 \pm 2.90 \mathrm{bc}$ & $60.50 \pm 6.66 \mathrm{~b}$ \\
T3 & $1.53 \pm 0.09$ & $40.72 \pm 3.52 \mathrm{c}$ & $50.46 \pm 5.00 \mathrm{~b}$ \\
\hline
\end{tabular}

Different small letter within column means a significant difference $(\mathrm{P}<0.05)$ between treated groups.

Table 3: Effect of different doses of melatonin on numerous biochemical parameter concentrations in plasma of ewes after 1 hour of treatment (Mean $\pm \mathrm{SE}$ )

\begin{tabular}{lccccc}
\hline Groups & \multicolumn{5}{c}{ Parameters } \\
\cline { 2 - 6 } & $\begin{array}{c}\text { Total protein } \\
(\mathrm{g} / 100 \mathrm{ml})\end{array}$ & $\begin{array}{c}\text { Albumin } \\
(\mathrm{g} / 100 \mathrm{ml})\end{array}$ & $\begin{array}{c}\text { Cholesterol } \\
(\mathrm{mg} / 100 \mathrm{ml})\end{array}$ & $\begin{array}{c}\text { Glucose } \\
(\mathrm{mg} / 100 \mathrm{ml})\end{array}$ & $\begin{array}{c}\text { Vitamin C } \\
(\mathrm{mg} / 100 \mathrm{ml})\end{array}$ \\
\hline Control & $5.74 \pm 0.73$ & $3.04 \pm 0.11$ & $91.2 \pm 6.09 \mathrm{a}$ & $25.7 \pm 1.02 \mathrm{~b}$ & $5.34 \pm 0.29$ \\
T1 & $5.69 \pm 0.79$ & $3.80 \pm 012$ & $87.0 \pm 5.54 \mathrm{a}$ & $37.1 \pm 1.23 \mathrm{a}$ & $5.96 \pm 0.30$ \\
T2 & $5.61 \pm 0.76$ & $3.03 \pm 0.11$ & $72.5 \pm 5.87 \mathrm{~b}$ & $35.8 \pm 1.31 \mathrm{a}$ & $5.34 \pm 0.28$ \\
T3 & $5.71 \pm 0.80$ & $3.66 \pm 0.11$ & $64.9 \pm 5.43 \mathrm{~b}$ & $41.4 \pm 1.19 \mathrm{a}$ & $5.76 \pm 0.28$ \\
\hline
\end{tabular}

Different small letter within column means significant difference $(\mathrm{P}<0.05)$ between treated groups.

The concentration of cholesterol was significantly decreased in treating ewes with melatonin at two doses 12 and $15 \mathrm{mg} /$ head compared with control and T2 groups. The concentration of glucose was higher in the treated groups compared with the control group. There were no significant differences presented between groups in vitamin $\mathrm{C}$ concentration after 1 hour of melatonin treatment. 
There was a significant increase in progesterone concentration during mid-gestation in all groups compared with early and late gestation periods (Table 4). There were no significant differences shown between groups in thyroxin concentration during the gestation period except in the first month, where, there was a significant decrease in $\mathrm{T} 1$ and T2 treated groups compared with control. However, thyroxin concentration showed significant increase in the first month of gestation and then declined gradually in the fifth month from 54.29 to $37.41 \mathrm{ng} / \mathrm{ml}$. There were no significant differences found between groups in cortisol concentration during gestation. Whereas, there was a significant increase in the concentration of cortisol in first and second months of gestation in comparison with other months $76.92,68.83,40.66,48.19,45.31 \mathrm{ng} / \mathrm{ml}$ for five months respectively.

Table 4: Effect of different doses of melatonin on numerous hormone concentrations ( $\mathrm{ng} / \mathrm{ml})$ in serum of pregnant ewes (Mean $\pm \mathrm{SE})$

\begin{tabular}{|c|c|c|c|c|c|}
\hline Period & No. & Groups & Progesterone & Thyroxin & Cortisol \\
\hline \multirow{4}{*}{ First Mo. } & 3 & Control & $2.18 \pm 0.09$ & $58.11 \pm 4.40 \mathrm{a}$ & $78.01 \pm 4.05$ \\
\hline & 5 & $\mathrm{~T} 1$ & $2.50 \pm 0.06$ & $50.10 \pm 3.80 \mathrm{~b}$ & $81.15 \pm 6.66$ \\
\hline & 6 & $\mathrm{~T} 2$ & $2.90 \pm 0.05$ & $53.17 \pm 3.61 \mathrm{ab}$ & $73.25 \pm 5.00$ \\
\hline & 6 & $\mathrm{~T} 3$ & $2.57 \pm 0.08$ & $55.80 \pm 3.67 \mathrm{a}$ & $75.30 \pm 4.81$ \\
\hline Mean & & & $2.53 \pm 0.09 \mathrm{D}$ & $54.29 \pm 3.61 \mathrm{~A}$ & $76.92 \pm 6.62 \mathrm{~A}$ \\
\hline \multirow{4}{*}{ Second Mo. } & 3 & Control & $3.55 \pm 0.10$ & $50.11 \pm 3.05$ & $75.55 \pm 6.51$ \\
\hline & 5 & $\mathrm{~T} 1$ & $3.97 \pm 0.09$ & $49.12 \pm 3.64$ & $62.61 \pm 5.05$ \\
\hline & 6 & $\mathrm{~T} 2$ & $3.72 \pm 0.07$ & $48.12 \pm 2.61$ & $73.07 \pm 6.11$ \\
\hline & 6 & $\mathrm{~T} 3$ & $3.99 \pm 0.08$ & $44.11 \pm 2.40$ & $64.11 \pm 4.92$ \\
\hline Mean & & & $3.80 \pm 0.09 \mathrm{C}$ & $47.86 \pm 2.82 \mathrm{~B}$ & $68.83 \pm 5.82 \mathrm{~A}$ \\
\hline \multirow{4}{*}{ Third Mo. } & 3 & Control & $5.10 \pm 0.10$ & $43.43 \pm 2.80$ & $36.30 \pm 5.70$ \\
\hline & 5 & $\mathrm{~T} 1$ & $5.40 \pm 0.09$ & $42.06 \pm 3.01$ & $44.04 \pm 4.83$ \\
\hline & 6 & $\mathrm{~T} 2$ & $5.97 \pm 0.11$ & $40.11 \pm 2.61$ & $39.56 \pm 6.00$ \\
\hline & 6 & $\mathrm{~T} 3$ & $5.72 \pm 0.08 \mathrm{~B}$ & $39.15 \pm 2.11$ & $42.77 \pm 6.27 \mathrm{~B}$ \\
\hline Mean & & & $5.54 \pm 0.12$ & $41.18 \pm 3.09 \mathrm{C}$ & $40.66 \pm 5.90$ \\
\hline \multirow{4}{*}{ Fourth Mo. } & 3 & Control & $7.00 \pm 0.11$ & $41.18 \pm 2.80$ & $49.01 \pm 6.11$ \\
\hline & 5 & $\mathrm{~T} 1$ & $7.90 \pm 0.13$ & $39.90 \pm 2.60$ & $46.58 \pm 6.80$ \\
\hline & 6 & $\mathrm{~T} 2$ & $7.94 \pm 0.09$ & $40.15 \pm 2.96$ & $43.11 \pm 6.31$ \\
\hline & 6 & $\mathrm{~T} 3$ & $7.49 \pm 0.08 \mathrm{~A}$ & $38.89 \pm 3.11 \mathrm{C}$ & $48.19 \pm 5.11 \mathrm{~B}$ \\
\hline Mean & & & $7.58 \pm 0.08$ & $40.02 \pm 2.46$ & $46.72 \pm 5.40$ \\
\hline \multirow{4}{*}{ Fifth Mo } & 3 & Control & $1.11 \pm 0.01$ & $39.11 \pm 2.02$ & $42.30 \pm 4.62$ \\
\hline & 5 & $\mathrm{~T} 1$ & $1.98 \pm 0.02$ & $35.62 \pm 3.41$ & $46.21 \pm 6.30$ \\
\hline & 6 & $\mathrm{~T} 2$ & $1.47 \pm 0.01$ & $36.04 \pm 2.81$ & $45.62 \pm 6.72$ \\
\hline & 6 & $\mathrm{~T} 3$ & $1.39 \pm 0.01$ & $38.90 \pm 2.00$ & $47.13 \pm 5.90 \mathrm{~B}$ \\
\hline Mean & & & $1.70 \pm 0.01 \mathrm{D}$ & $37.41 \pm 2.50 \mathrm{C}$ & $45.31 \pm 4.11$ \\
\hline
\end{tabular}

Different capital and small letter within column mean significant difference $(\mathrm{P}<0.05)$ between periods and treated groups respectively.

A significant effect of melatonin treatment on total protein, albumin, cholesterol, glucose and vitamin $\mathrm{C}$ concentrations during gestation months are observed in table 5. Protein concentration was increased significantly in both the early and late gestation compared with mid once. There were no significant differences obtained between groups in albumin concentration in all gestation months.

There was a significant decrease in cholesterol concentration in $\mathrm{T} 1$ and $\mathrm{T} 3$ treated groups as compared with control in the first two months of gestation. The concentration of cholesterol showed significant decreased in the first month of gestation and continue decline for the last month gradually.
The glucose concentration showed a significant increase in mid-gestation compared with early and late gestation. Vitamin C concentration showed a significant increase in the first month of parturition compared with other months.

\section{Discussion}

Melatonin treatment at a doses 12 and $15 \mathrm{mg} /$ head showed an increase in the percentage of fertility and twinning in ewes, whereas, the placenta weight was higher in ewes T2 group. Melatonin treatment may stimulate the hypothalamus cells to release GnRH and causes an effect on gonadal function or increases the RNA of GnRH in the 
hypothalamus $(15,16)$. However, this increase may be the first step to the stimulation of FSH secretion and follicular growth in ovary and when arises estradiol level lead to stimulate LH secretion by the estradiol positive feedback. Or may be due to that melatonin have an effect on ovarian activity and progesterone secretion during the luteal phase (17). Those results agreed with the results of Uslu et al. (18) who found a rise in lambing percentage from 50 to $70 \%$ as compared with a control group in fat-tailed Morkaraman ewes and this percentage increased from 70 to $80 \%$ when melatonin was combined with norgestomet, but, they did not record any changes in twinning rate. Furthermore, Horoz et al. (19) reported that the pregnancy rate increased from 75 to $85 \%$ after treating Kivircik ewes melatonin in comparison with non - treated group (control), while the twinning rate increased from 43.6 to $52.9 \%$ in non-treated and treated groups respectively. Although, Bonev (2) treated melatonin to three different breeds of sheep (Awassi, Pleven Blackhead X Awassi and lle de France) during different seasons, he found a significant increase in fertility, pregnancy rate and twinning percentage and suggested that increase in ovulation rate causes more growth and development ovum. There were no significant differences shown between groups in progesterone concentration after 1 hour of treatment. Similar results for this data was also observed by Kassim et al. (20) in Arabi ewes. Thyroxin was decreased in all treated groups compared with control. This result corresponds with the results of Dönmez et al. (6) and Vriend et al. (21), which they reported a decrease in thyroxin concentration in ewes and goats after melatonin treatment. The reason of decreased cortisol after melatonin treatment may be due to that melatonin has an effect on inhibition the ACTH secretion from the hypothalamus, which causes falling in cortisol secretion (22). This result was similar to that found by Sejian and Srivastava (23) in Indian goats.

Table 5: Effect of different doses of melatonin on numerous biochemical parameters in serum of pregnant ewes (Mean $\pm \mathrm{SE}$ )

\begin{tabular}{|c|c|c|c|c|c|c|c|}
\hline Period & No. & Groups & $\begin{array}{c}\text { Total protein } \\
(\mathrm{g} / 100 \mathrm{ml})\end{array}$ & $\begin{array}{l}\text { Albumin } \\
(\mathrm{g} / 100 \mathrm{ml})\end{array}$ & $\begin{array}{l}\text { Cholesterol } \\
(\mathrm{mg} / 100 \mathrm{ml})\end{array}$ & $\begin{array}{c}\text { Glucose } \\
(\mathrm{mg} / 100 \mathrm{ml})\end{array}$ & $\begin{array}{c}\text { Vitamin C } \\
(\mu \mathrm{g} / 100 \mathrm{ml})\end{array}$ \\
\hline \multirow{4}{*}{ First Mo. } & 3 & Control & $6.17 \pm 0.28$ & $3.47 \pm 0.11$ & $116.2 \pm 7.05 \mathrm{a}$ & $22.7 \pm 1.03$ & $3.82 \pm 0.31$ \\
\hline & 5 & $\mathrm{~T} 1$ & $6.55 \pm 0.25$ & $3.25 \pm 0.09$ & $84.9 \pm 4.54 \mathrm{~b}$ & $20.7 \pm 1.12$ & $4.36 \pm 0.30$ \\
\hline & 6 & $\mathrm{~T} 2$ & $7.17 \pm 0.23$ & $4.00 \pm 0.10$ & $100.8 \pm 6.90 \mathrm{a}$ & $25.9 \pm 1.14$ & $4.38 \pm 0.29$ \\
\hline & 6 & T3 & $6.61 \pm 0.26$ & $3.50 \pm 0.11$ & $79.9 \pm 5.66 \mathrm{~b}$ & $27.2 \pm 1.07$ & $4.03 \pm 0.28$ \\
\hline Mean & & & $6.62 \pm 0.37 \mathrm{~A}$ & $3.55 \pm 0.08$ & $98.6 \pm 5.90 \mathrm{~A}$ & $24.1 \pm 1.12 \mathrm{C}$ & $4.14 \pm 0.29 \mathrm{~A}$ \\
\hline \multirow{4}{*}{ Second Mo. } & 3 & Control & $5.10 \pm 0.22$ & $4.13 \pm 0.07$ & $123.4 \pm 7.21 \mathrm{a}$ & $27.4 \pm 1.13$ & $2.66 \pm 0.24$ \\
\hline & 5 & $\mathrm{~T} 1$ & $5.11 \pm 0.19$ & $3.42 \pm 0.08$ & $77.7 \pm 5.21 \mathrm{~b}$ & $31.6 \pm 1.15$ & $2.97 \pm 0.27$ \\
\hline & 6 & $\mathrm{~T} 2$ & $5.27 \pm 0.24$ & $3.46 \pm 0.09$ & $82.7 \pm 6.66 \mathrm{~b}$ & $30.9 \pm 1.13$ & $2.72 \pm 0.29$ \\
\hline & 6 & $\mathrm{~T} 3$ & $5.39 \pm 0.20$ & $3.83 \pm 0.07$ & $89.7 \pm 6.00 \mathrm{~b}$ & $33.2 \pm 1.14$ & $2.91 \pm 0.26$ \\
\hline Mean & & & $5.21 \pm 0.21 \mathrm{BC}$ & $3.71 \pm 0.09$ & $93.3 \pm 7.86 \mathrm{AB}$ & $30.7 \pm 1.18 \mathrm{~B}$ & $2.81 \pm 0.31 \mathrm{~B}$ \\
\hline \multirow{4}{*}{ Third Mo. } & 3 & Control & $4.96 \pm 0.16$ & $3.67 \pm 0.10$ & $90.1 \pm 6.07$ & $51.8 \pm 1.17$ & $2.55 \pm 0.25$ \\
\hline & 5 & $\mathrm{~T} 1$ & $4.26 \pm 0.17$ & $3.76 \pm 0.11$ & $94.5 \pm 6.21$ & $56.1 \pm 1.16$ & $2.62 \pm 0.23$ \\
\hline & 6 & $\mathrm{~T} 2$ & $4.67 \pm 0.18$ & $3.95 \pm 0.0 .8$ & $80.0 \pm 6.90$ & $60.4 \pm 1.20$ & $2.31 \pm 0.29$ \\
\hline & 6 & $\mathrm{~T} 3$ & $4.28 \pm 0.19$ & $4.90 \pm 0.08$ & $88.9 \pm 6.43$ & $54.7 \pm 1.16$ & $3.00 \pm 0.30$ \\
\hline Mean & & & $4.54 \pm 0.14 \mathrm{C}$ & $3.95 \pm 0.09$ & $88.3 \pm 7.00 \mathrm{~B}$ & $55.7 \pm 1.10 \mathrm{~A}$ & $2.62 \pm 0.28 \mathrm{~B}$ \\
\hline \multirow{4}{*}{ Fourth Mo. } & 3 & Control & $6.21 \pm 0.23$ & $3.82 \pm 0.10$ & $60.6 \pm 5.90$ & $33.2 \pm 1.12$ & $2.59 \pm 0.29$ \\
\hline & 5 & $\mathrm{~T} 1$ & $5.57 \pm 0.21$ & $3.52 \pm 0.08$ & $69.1 \pm 5.32$ & $35.8 \pm 1.13$ & $2.29 \pm 0.28$ \\
\hline & 6 & $\mathrm{~T} 2$ & $5.50 \pm 0.18$ & $3.65 \pm 0.09$ & $65.3 \pm 5.02$ & $39.4 \pm 1.11$ & $2.20 \pm 0.27$ \\
\hline & 6 & $\mathrm{~T} 3$ & $6.02 \pm 0.19$ & $3.90 \pm 0.08$ & $58.7 \pm 5.12$ & $36.5 \pm 1.11$ & $2.63 \pm 0.28$ \\
\hline Mean & & & $5.82 \pm 0.20 \mathrm{~A}$ & $3.72 \pm 0.09$ & $63.4 \pm 5.55 \mathrm{C}$ & $36.2 \pm 1.19 \mathrm{~B}$ & $2.42 \pm 0.29 \mathrm{~B}$ \\
\hline \multirow{4}{*}{ Fifth Mo } & 3 & Control & $5.46 \pm 0.19$ & $3.87 \pm 0.09$ & $64.5 \pm 5.65$ & $27.8 \pm 1.00$ & $2.50 \pm 0.30$ \\
\hline & 5 & T1 & $6.70 \pm 0.21$ & $4.78 \pm 0.11$ & $58.6 \pm 6.00$ & $23.9 \pm 1.07$ & $2.51 \pm 0.26$ \\
\hline & 6 & $\mathrm{~T} 2$ & $6.19 \pm 0.23$ & $3.50 \pm 0.10$ & $55.4 \pm 5.76$ & $23.5 \pm 1.08$ & $2.31 \pm 0.27$ \\
\hline & 6 & T3 & $5.53 \pm 0.21$ & $3.85 \pm 0.10$ & $56.8 \pm 5.87$ & $24.9 \pm 1.10$ & $2.88 \pm 0.27$ \\
\hline Mean & & & $5.97 \pm 0.23 \mathrm{AB}$ & $4.00 \pm 0.09$ & $58.8 \pm 5.33 \mathrm{C}$ & $25.0 \pm 1.12 \mathrm{C}$ & $2.55 \pm 0.29 \mathrm{~B}$ \\
\hline
\end{tabular}

Different capital and small letter within column mean significant difference $(\mathrm{P}<0.05)$ between periods and treated groups respectively.

The concentration of cholesterol decreased in $\mathrm{T} 3$ and $\mathrm{T} 4$ groups compared with control and T2 groups. According to
Darul and Kruczyńska (24) whose recorded a decline in cholesterol level in dairy goats over 4 hours of melatonin 
treatment and they suggested that melatonin may play a role in controlling lipid metabolism in the animals through its influence on the level of insulin hormone that have an effect on lipid- carbohydrate metabolism. This result agrees with the results of Kassim et al, (20) and Darul and Kruczyńska (24) in Arabi ewes in and dairy goats respectively. Glucose concentration was higher in the treated groups in comparison with control. This can be explained by the direct influence of melatonin on the function of hepatic cells in regulating the plasma glucose (25). Also, melatonin has an effect on the insulin secretion from the pancreas gland (24). This result agrees with the observation by the authors $(20,23,26)$ in Arabi ewes, female Marwai goats and dairy cows respectively.

There was an increase in progesterone concentration during mid-gestation in all groups as compared with early and late gestation periods, this might be to that placenta after completing its development during the second month of gestation sharing with the ovary in elevation of progesterone level in the mother's circulation (27), or may be due to the positive correlation between the level of progesterone and placenta size (28). This result was agreed with Bashandy et al. (29) and Yotov (30). Thyroxin concentration increased in the first month of gestation and then declined gradually in the fifth month. The reason for the elevation in the thyroxin level in early gestation may be due to that thyroid hormone is necessary for this period to meet the growth and energy requirements of the fetus development (31). In addition, the lower passage of thyroid hormone from mother to fetus through the placenta, especially before the sixth and eighth weeks of embryonic life (32). Therefore, naturally, the level of thyroxin in the mother's circulation became higher. Whereas, the reason for the decreasing of this hormone in the last month that fetus became more developed and needs more iodine to the synthesis it is thyroxin hormone, the fetus will take iodine from the only available source (mother's circulation) $(33,34)$, and that will cause a negative effect on mother's thyroxin synthesis. Similar results were also observed by Colodel et al. (35), who reported that thyroxin level increased in the serum of pregnant Lanada Serrana ewes during mid-gestation and decreased during the end of it. In addition, there was an increase in the concentration of cortisol in first and second months of gestation in comparison with other months. As known, cortisol is a glucocorticoid hormone and considered as an anti-stress hormone, which normally increases when animals are under stress condition such as pregnancy and take some time to return to normal range (36). According to Firat et al. (37), the level of cortisol increases during 100 days of gestation and then decline during late gestation in Sakiz ewes.

Protein concentration was higher in early and late gestation as compared with mid once, this result can explain by the metabolism of proteins and transfer of the amino acids through the placenta are increasing during this period to meet the requirements of growth and development of fetus muscles and that led to dropping in the mother circulation proteins (38). This result agrees with the results of Khatun et al. (39) and Marai et al. (40). There was a decrease in cholesterol concentration in $\mathrm{T} 1$ and $\mathrm{T} 3$ treated groups as compared with control in first and second months of gestation, this might be due to variation in the body score of ewes or to the accumulation effect of melatonin treatment. Also, the concentration of cholesterol decreased in the first month of gestation and continued gradually to the last month. The reason of the decrease in cholesterol concentration during parturition may be due to the increase in cholesterol uptake by the corpus luteum to produce progesterone hormone (39), Additionally, there is more need for the energy sources to meet the growing fetus, which supplied from the mother's blood (27). Our result has agreed with the results of Piccione et al. (41) and Kaushik and Bugalia (42). Glucose concentration was elevated in mid-gestation as compared with early and late gestation. According to Firat et al. (37) in their study on Sakiz pregnant ewes, glucose concentration does not differ significantly between the periods of gestation. Furthermore, the decline in glucose level in early gestation may be due to provide the energy for growth the fetus. While, the decline in glucose level in late-gestation may due to using it to provide the carbohydrate for colostrum and milk production just before starting lactation stage (43).

The present study concluded that melatonin treatment at doses 12 and $15 \mathrm{mg} /$ head improves reproductive performance (fertility percentage, twinning rate and the number of lambs born. Additionally, melatonin treatment leads to reduce the gestation stage stress and increase the body metabolism cells through decline cortisol concentration and raises glucose concentration in serum. The gestation stage has a negative effect on the concentrations of thyroxin, cholesterol and vitamin C. Furthermore, this stage causes changes on concentrations of some biochemical parameters such as cortisol, total protein and glucose.

\section{Acknowledgements}

The authors would like to thank the owner of the commercial animal field to allow us to use his animals during the study. Also, we give our appreciation to Dr. Asaad Yahia Aayid (Professor in the department of animal production, college of agriculture, University of Basrah) for his help in statistical analysis.

\section{References}

1. Al-Saigh MNR, Al-Qas JE. Sheep and Goat Production. In: The reproduction. Dar Al-Hikma: University of Basrah; 1999. 57-170 p. 
2. Bonev G. Effect of melatonin treatment on fertility, fecundity, litter size and sex ratio in ewes. Agric Sci Technology. 2012;4:113-116.

3. Skotnicka E, Heynczak A. Melatonin and its possible role in regulation of water and electrolyte metabolism. Medycyna Wet. 2001:57:299-303.

4. Kowiak P, Przybylska K, Bejna E. Changes in some lipid indices in rat blood, liver and muscles after injections of melatonin. Roczniki Akademii Rolniczej Poznan. 1999;51:175-180.

5. Vanecek I. Cellular mechanism of melatonin action. Physiol Rev. 1998;78:687-721. DOI: 10.1152/physrev.1998.78.3.687

6. Dönmez N, Karaca F, Belge F, Tayyar C. The effects of melatonin application on some hematological parameters and thyroid hormones and testosterone in male goats' non-breeding season. Vet Arhiv. 2004;74:281-287

7. Yellon SM, Foster DL, Longo LD, Suttie JM. Ontogeny of the pineal melatonin rhythm and implications for reproductive development in domestic ruminants. Anim Reprod Sci. 1992;30:91-112. doi.org/10.1016/0378-4320(92)90007-Z

8. Malpaux B, Migaud M, Tricoire H, Chemineau P. Biology of mammalian photoperiodism and the critical role of the pineal gland and melatonin. J Bio Rhythms. 2001;16:336-347. DOI: 10.1177/074873001129002051

9. Reiter RJ, Tan DX, Manchester LC, Paredes SD, Mayo JC, Sainz RM. Melatonin and reproduction revisited. Bio Reprod. 2009;81:445-456. DOI: 10.1095/biolreprod.108.075655

10. Kal'atová, J., Vlčková, R., Sopkova, D., \& Maraček, I. (2009). The effect of melatonin, its combination with FGA and eCG and OvSynch protocol on the levels of steroid hormone and morphometry of ovaries during oestrus season of ewes. Slovak Journal of Animal Science, 42(Supplement), 30-34.

11. Abecia JA, Valares JA, Forcada F, Palaccin I, Martin S, Martino A. The effect of melatonin on the reproductive performance of three sheep breeds in Spain. Small Rumin Res. 2007;69:10-16. doi.org/10.1016/j.smallrumres.2005.12.018

12. deNicolo G, Morris ST, Kenyon PR, Morel PCH, Parkinson TJ. Melatonin improved reproductive performance in sheep bred out of season. Anim Repod Sci. 2008;109:124-133. DOI: 10.1016/j.anireprosci.2007.10.012

13. Mindlin RL, Butler AM. The determination of ascorbic acid in plasma: A macro method and micro method. J Biol Chem. 1938;22:673-686.

14. SPSS. Statistical Packages of Social Sciences. Version 9.00. Cany: SPSS Inc.; 2016.

15. Bernard DJ, Abuav NR, Horton TH, Turek FW. Photoperiod effect on gonadotropin - releasing hormone $(\mathrm{GnRH})$ content and the GnRHimmunoreactive neuronal system of male Siberian hamster. Biol Reprod. 1999;60:272-276 DOI: 10.1095/biolreprod60.2.272

16. Wheaton JE, Pohi HA, Windels HF. Effect of melatonin and progesterone administered to ewes in spring and summer. J Anim Sci. 1990;68:923-930. DOI: 10.2527/1990.684923x

17. McEvoy TG, Robinson JJ, Aitken RP, Robertson IS. Melatonin treatment of embryo donor and recipient ewes during estrus affects the endocrine status, but not ovulation rate, embryo survival or pregnancy. Theriogenol. 1998;49:943-955. DOI: 10.1016/s0093-691x(98)00043-0

18. Uslu BA, Tasal I, Gulyuz F, Sendag S, Ucar O, Goericke-Pesch S, Wehrend A. Effects of estrus synchronization using melatonin and norgestomet implants followed by ECG injection upon reproductive traits of fat-tailed Morkaraman ewes during suckling, anoestrus season. Small Ruminant Res. 2012;108:102-106. doi.org/10.1016/j.smallrumres.2012.07.002

19. Horoz H, Kasikci G, Kemal A K, Alkan S, Sonmez C. Controlling the breeding season using melatonin and progestagen in Kivircik ewes. Turk J Vet Anim Sci. 2003;27:301-305.

20. Kassim WY, Al-Helou MF, Al-Rishdy KA. The influence of melatonin hormone's treatment on sex hormones and some biochemical parameters on Arabi sheep and local goats. Life Sci Arch. 2016;2:773-780.doi:10.21276/1sa.2016.2.5.15
21. Vriend J, Richardson BA, Vaughan MK, Johnsony L, Reiter RJ. Effects of melatonin on thyroid physiology of female hamsters. Neuroendocrinol. 1982;35:79-85. DOI: 10.1159/000123359

22. Konakchieva R, Mitev Y, Almeida OF, Patchev VK. Chronic melatonin treatment and the hypathalamopituitary-adrenal axis in the rat: attenuation of the secretory response to stress and effects on hypothalamic neuropeptide content and release. Biol Cell. 1997;89:587-596. doi.org/10.1016/S0248-4900(98)80163-9

23. Sejian V, Srivastava RS. Effects of melatonin on adrenal cortical functions of Indian goats under thermal stress. Vet Med Inter. 2010;1:1-6. doi: 10.4061/2010/348919

24. Darul K, Kruczyńska H. Changes in selected blood metabolites associated with melatonin administration in dairy goats. Folia biological (Kraków). 2004;52:239-241. DOI: 10.3409/1734916044527539

25. Poon AM, Choy EH, Pang SF. Modulation of blood glucose by melatonin: a direct action on melatonin receptors in mouse hepatocytes. Biol Signals Recept. 2001;10:367-379. DOI: $10.1159 / 000046904$

26. Darul K, Kruczyńska H. Changes in selected biochemical blood parameters in dairy cows after administration of melatonin. J Anim Feed Sci. 2005;14:243-246 DOI: 10.22358/jafs/70524/2005.

27. Gray CA, Bartol BJ, Tarleton AA, Wiley, GA, Johnson FW, Bazer TE. Developmental biology of uterine glands. Biol Reprod. 2001;65:1311-1323. DOI: 10.1095/biolreprod65.5.1311

28. Kulcsár M. Clinical endocrinology of leptin in ruminants $[\mathrm{PhD}$ Dissertation]. France: Postgraduate School of Veterinary Science; 2007. 1-25 p.

29. Bashandy MM, Mostafa DS, Rahman GH. Some biochemical, cytogenetic and reproductive studies with the use of hormones and flushing with lupine grains in sheep. Global Vet. 2010;5:88-96.

30. Yotov S. Determination of the number of fetuses in sheep by means of blood protestation assay and ultrasonography. Bulg J Vet Med. 2007;3:185-193.

31. Akasha MA. Concentration of thyroid hormones in blood serum and milk of Holstein cows at different stages of lactation and pregnancy. $\mathrm{J}$ Sebha Univ. 2008;7:22-27.

32. Bryden MM, Evans HE, Binns W. Embryology of the sheep. The alimentary tract and associated glands. J Morphol. 1972;138:187-206. DOI: $10.1002 /$ jmor. 1051380205

33. Refsal KR, Nachreiner RF, Anderson CR. Relationship of season, herd lactation age, and pregnancy with the thyroxin, 3, 5, 3 triiodothyronine in Holstein cows. Domestic Anim Endocrinol. 1984;1:225-234. doi.org/10.1016/0739-7240(84)90003-1

34. Bergamashi MM, Vicente WRR, Barbosa RT, Marques JA, Freitas AR. Perfis plasmáticos maternos de triiodotironina e tiroxina em fêmeas nelore e crescimento fetal bovino. Rev Bras Med Vet. 2002;25:35-39.

35. Colodel MM, Martins E, Martins VMV, Marques AP. Serum concentration of thyroid hormones in Crioula Lanada Serrana ewes in gestation and lactation. Arch Zootec 2010;59:509-517.

36. Alves AC, Alves NG, Ascari IJ, Junqueira FB, Maciel LFS, Garcia IFF, Lima RR. Performance and serum cortisol concentration in Santa Inês lambs under different suckling schemes. R Bras Zootec. 2016;45:546-553. doi.org/10.1590/s1806-92902016000900007

37. Firat A, Ozpinar A. Metabolic profile of pre-pregnancy, pregnancy and early lactation in multiple lambing Sakiz ewes: Changes in plasma glucose, 3-hydroxybutyrate and cortisol levels. Ann Nutr Metab. 2002:46:57-61. DOI: $10.1159 / 000057641$

38. Antunovic Z, Senjcic D, Šperanda M, Liker B. Influence of the season and the reproductive status of ewes on blood parameters. Small Rum Res. 2002;45:39-44. doi.org/10.1016/S0921-4488(02)00109-8

39. Khatun A, Wani GM, Bhat JI, Choudhury AR, Khan MZ. Biochemical indices in sheep during different stages of pregnancy. Asian J Anim Vet Adv. 2011;6:175-181.doi:103923/ajava.2011.175.181

40. Marai IF, Darawany EL, Abou-Fandoud AA, Abdel-Hafez EL. Serum blood components during pre-estrus, Estrus and pregnancy phases in 
Egyptian Suffolk ewes as affected heat stress, under the conditions of Egypt. Anim Prod Res Egypt J Sheep, Goats and Desert Anim Sci. 2006; 1:47-62. DOI: 10.21608/ejsgs.2006.28074

41. Piccione G, Caola G, Giannetto C, Grasso F, Runzo SC, Zumbo A, Pennisi P. Selected biochemical serum parameters in ewes during pregnancy, post-parturition, lactation and dry period. Anim Sci Papers and Reports. 2009;27:321-330.
42. Kaushik HK, Bugalia NS. Plasma total protein, cholesterol, minerals and transaminases during pregnancy in goats. Indian Vet $\mathrm{J}$. 1999;76:603-606. doi:10.3906/vet-1405-2

43. Manston R, Allen WM. The use of blood chemistry in monitoring the health of farm livestock. British Vet J. 1981;137:241-253. doi.org/10.1016/S0007-1935(17)31681-0 